\title{
Toward a Critical Children's Museology: The Anything Goes Exhibition at the National Museum in Warsaw
}

\author{
Monica Eileen Patterson
}

\begin{abstract}
For decades, Museum Studies scholars have called for a new 'critical museology' with greater inclusion of marginalized communities and diversification of exhibition content, but children have been largely ignored in these efforts. This paper explores the possibilities for what I call a new 'Critical Children's Museology' through in-depth analysis of the Anything Goes exhibition at the National Museum in Warsaw, Poland in 2016. Curated by 69 children, this ground-breaking exhibition radically broke from current and traditional museological practice by offering prominent institutional space and professional support for children's cultural production in the form of curated exhibition galleries and programming. I analyze the exhibition, its production process, and its strengths and limitations to consider the possibilities and challenges of bringing child-centred praxis into museology. This work contributes to the larger charge of democratizing museum and curatorial practice by upending the patronizing view of children as passive recipients of museum offerings, focusing instead on their capacities for cultural production, critical interpretation, and curatorial innovation.
\end{abstract}

Key words: children, museum, curating, exhibitions, Poland

\section{Introduction}

In recent decades, museums have been critiqued for their authoritarianism and elitism, their colonial origins and legacies, and the ways they perpetuate patriarchy, heteronormativity, white supremacy, and nationalism (Vergo 1989; Shelton 1990; Karp and Lavine 1991; Kirshenblatt-Gimblett 1998). While historically marginalized communities have taken museums and galleries to task for perpetuating their erasure and misrepresentation (Assembly of First Nations and The Canadian Museums Association 1994; Butler 2008; Sleeper-Smith 2009; Cooks 2011; Sandell et al. 2013; Kreps 2011; Truth and Reconciliation Commission of Canada 2015; Janes and Sandell 2019; Sullivan and Middleton 2019), children are a key group that remains outside of these movements and debates (Roberts 2006; Brookshaw 2009, 2016; Patterson and Friend 2021). ${ }^{1}$ Viewed in outmoded ways - as passive recipients of education and outreach - they have not been considered among other constituent groups as unfairly silenced potential contributors to exhibition content and curatorial practice. A recent edited collection on critical museology in and beyond Eastern Europe proclaimed that museums need to bring in a broader range of voices, and '[n]ot just guest curators, art critics, university professors, artists, scientists, or any other kinds of authorities whose collaboration with museum professionals has always been taken for granted', but '[o]utsiders of any other kind should also have a say in museum discourses' (Murawska-Muthesius and Piotrowski 2015: 127). At 25 per cent of the population, young people between the ages of 0 and 24 are an integral part of Polish (and any) society. ${ }^{2}$ Yet, none of the book's authors mentioned children as an underrepresented minority worthy of self-representation or active participation.

While the number of children's museums around the world is quickly increasing, mainstream institutions - including children's museums - rarely engage with children as significant co-producers of knowledge. Such work entails identifying approaches to producing 
museum content not just for or about children, but by and with them. As I have argued previously, children and youth, as experts on themselves and their experiences, have much to teach us about engaging, interactive, and inclusive exhibitions and programming (Patterson 2016). In the field of Child Studies, scholars have advocated for a shift from thinking about children as passive recipients who consume or internalize information handed down to them, to recognizing them as agents who bring their own knowledge, experience, and interpretive capacity to bear on the content they encounter. With the application of 'new' (Vergo 1989; Mairesse and Desvallées 2010), 'critical' (Shelton 1990), and 'post' (Hooper-Greenhill 2000) museological approaches, a parallel shift has occurred in the field of museology. Museum staff, particularly curators, are no longer seen as the only relevant interpreters of museum content. Their traditional role as elite experts who transfer canonized knowledge and values and tell visitors what they should think has been eroded by a push for dialogue and the inclusion of historically marginalized voices.

In the sections that follow, I explore the National Museum in Warsaw's Anything Goes exhibition, curated by 69 children over the course of six months in 2016. I analyze the content and design of this ground-breaking exhibition, its production process, and its strengths and limitations to consider the possibilities and challenges of bringing child-centred praxis into museology. As an example of what I call a new 'Critical Children's Museology', Anything Goes contributes in important and under-recognized ways to the larger charge of democratizing museum and curatorial practice, by upending the patronizing view of children as merely passive recipients of museum content and programming, and focusing instead on their capacities for cultural production, critical interpretation, and curatorial innovation. It also contributes to a fuller understanding of children's interests and the practical workings of the museum, as experienced through children's perspectives.

\section{The National Museum in Warsaw}

Founded in 1862, the Muzeum Narodowe w Warszawi (MNW), or National Museum in Warsaw, is one of the largest and oldest museums in Poland with a collection of more than 830,000 works of Polish and world art from antiquity to the present. ${ }^{3}$ Faced with an exhibition cancellation in 2015, the Museum's then director, Agnieszka Morawińska, moved to enact a long-held dream: to organize an exhibition curated by children. ${ }^{4}$ Her introduction to the exhibition catalogue notes that children typically visit the museum on school field trips, ${ }^{5}$ where they are often alienated from the moment they arrive: 'They wait in large, cold halls just to see work that is hung a bit too high for their view, or to peer through cases that do not let them see works very well' (Muzeum Narodowe w Warszawie 2016: 11, translation from Polish). They are then barraged with a list of rules: no running, no yelling, no touching, and no breaking off from the group. After that introduction, museum educators are expected to make the young visitors feel engaged and interested in the exhibitions (Muzeum Narodowe w Warszawie 2016: 11).

\section{Production Process}

Described by the MNW as a 'museum-educational experiment', ${ }^{6}$ the Anything Goes exhibition was curated by 69 six- to fourteen-year-old children (henceforth referred to as 'the curators') and installed in the museum's main exhibition space. The curators were divided into six curatorial teams. They convened every Saturday for six months (excluding holidays) for fourhour meetings and workshops where they learned from museum staff about the inner workings of the museum, including the handling of objects, preservation and restoration techniques, exhibition design, and other skills. In developing their initial ideas for the exhibition, the curators visited the collections and took mini-polaroid pictures of different objects to examine, research, and discuss.

Each team received an oversized sketchbook to document their curatorial process. The first task was to collectively establish a set of communal ground rules; these included edicts such as: don't interrupt, call everyone by their names, be friendly, and don't make anyone do anything (Muzeum Narodowe w Warszawie 2016). The sketchbooks also featured 
the curators' personal reflections, ideas, photographs, writing, and drawings. The project was coordinated by Education Department staff members Ania Knapek and Bożena Pysiewicz, who carefully chose educators as team leaders based on their knowledge of the MNW collection and their experience working with children. ${ }^{7}$ The educators' primary goals were to facilitate close cooperation, dialogue, and participation. According to Knapek, the tutors and children largely maintained a joyful atmosphere, with parents kept informed throughout the project. ${ }^{8}$

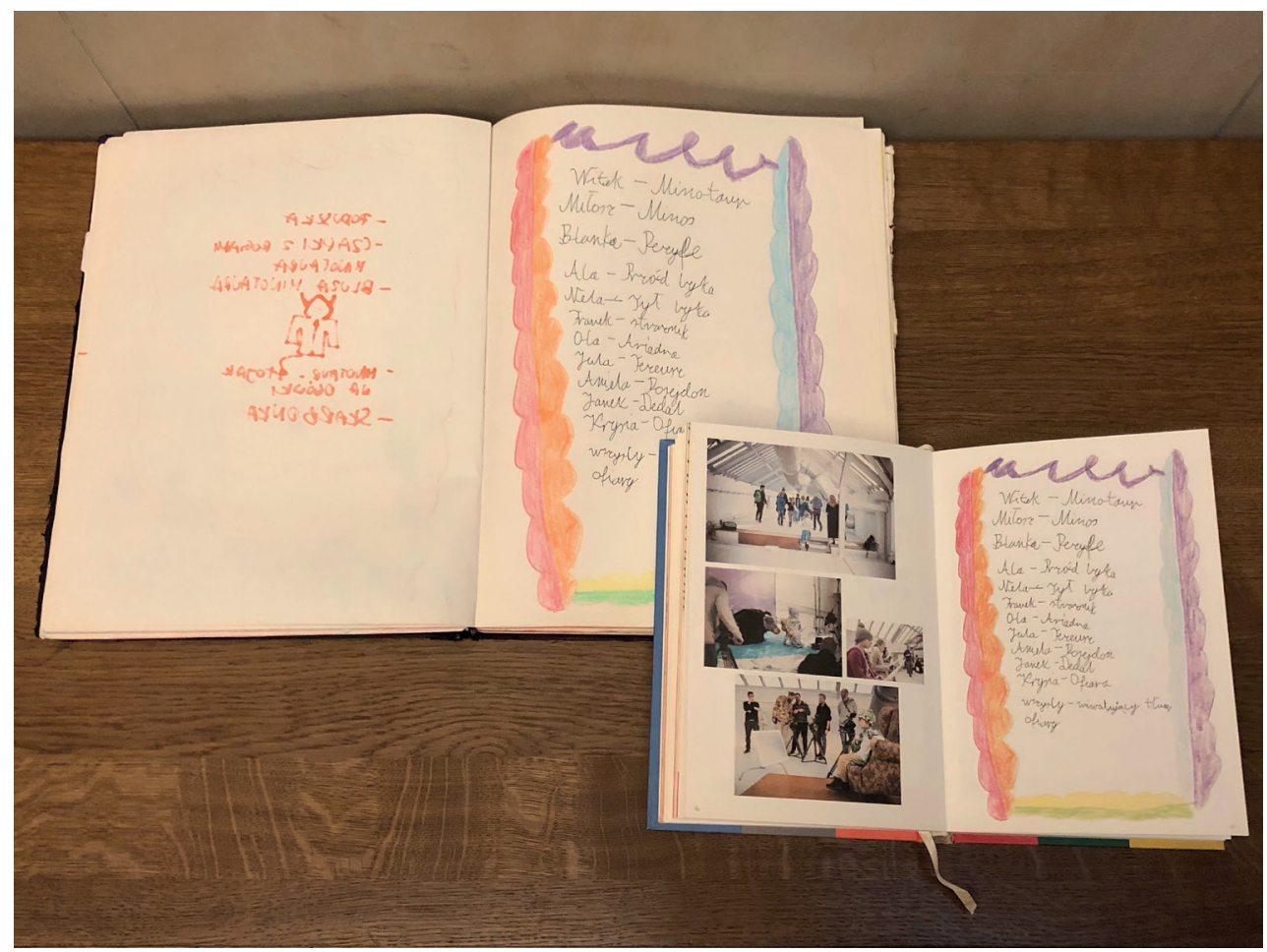

Figure 1: Pages from a curatorial team's sketchbook with reproduction in the Polish exhibition catalogue (Muzeum Narodowe w Warszawie 2016). Photo by author.

The young participants were recruited on a first-come, first-served basis through an open call for volunteer participants on the museum's website, newsletter, and Facebook page. Workshops were documented by adult volunteer photographers and videographers. Snack breaks and lunch provided opportunities for sociality, fun, replenishment, and the sharing of ideas. According to Knapek, the process was important, but so was the final product (Knapek 2016). The curators, their families, and museum staff were proud of the final exhibition, open from 28 February to 8 May 2016. The exhibition and its production process were documented in a 40-minute film, ${ }^{9}$ a 253-page Polish catalogue (Muzeum Narodowe w Warszawie 2016), and a 100-page English catalogue the following year (Morawińska 2017). In the museum gift shop, visitors could purchase the Polish catalogue, bookmarks, buttons, and a cardboard mask of a bull as mementos.

The young curators were responsible for all components of curating the exhibition: they determined the themes for their respective galleries, selected nearly 300 works for display, authored curatorial statements and labels, designed the layout of works and multimedia components, recorded audio guides, and created educational materials. As described on the MNW's website, Anything Goes presented 'works from all collections: objects of ancient and oriental art, artistic crafts, old and contemporary sculptures, photographs, drawings and graphics, coins and medals, clothing and paintings from various periods. ${ }^{10}$ The curators 
worked with adult contractors and professionals based at the MNW to help manifest some of their envisioned elements. They also helped produce the catalogue, which provided readers with a 'backstage' view of the production process. The children determined the structure of the catalogue (by team), in addition to its binding (sturdy hardback), content (lots of photos! And a letter from the Director, Agnieszka Morawińska, but no other adults), and cover design (featuring the six teams' colours and non-standard, 'freed' typography). They also helped create the promotional materials ${ }^{11}$ planned the opening reception, led tours of the exhibition, and gave interviews to television, radio, and online and print media reporters.

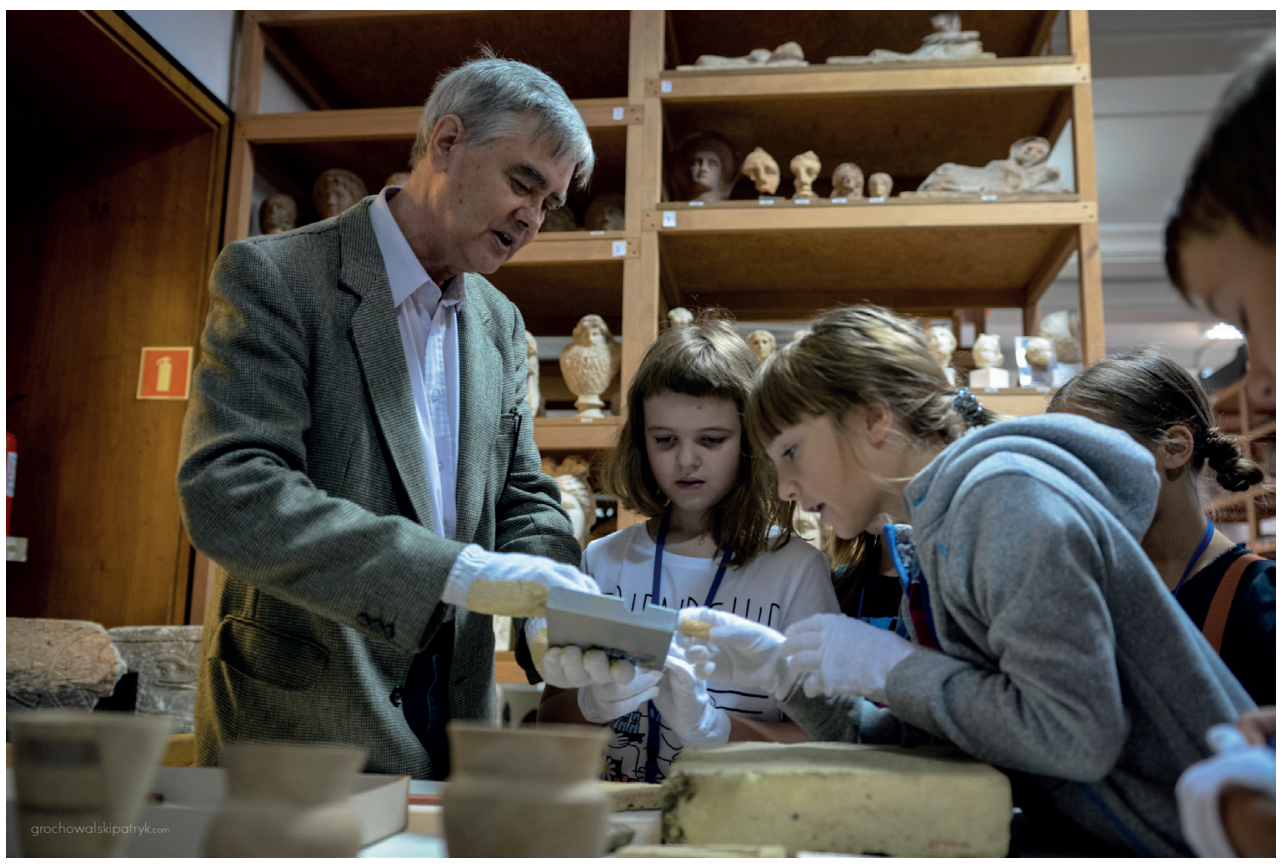

Figure 2: Curators and a member of the museum staff examine artefacts at the National Museum in Warsaw. Photo: National Museum in Warsaw.

\section{The Exhibition}

Anything Goes was not a minor sideshow, but occupied the museum's seven main temporary galleries on the ground floor. Despite the single title, there was no master narrative; each of the six exhibition galleries had its own atmosphere and curatorial approach, with a seventh used for educational programming and workshops. Standard curatorial features, including overarching themes, narrative, object labels, audio guides, gallery tours and educational prints were given unique twists. For example, works were displayed professionally, but at children's eye-level and at times with additional commentary in the curators' youthful handwriting.

The curators developed novel taxonomies for selecting and assembling works in each gallery. Leaping across time period and culture, and unconstrained by predetermined ideas of what constitutes 'good art' or technique, famous works were juxtaposed with unknown and never-before-exhibited items (Kielczewska and Pysiewicz 2016: 246). Repetition across galleries revealed the children's shared interest in animals and the mysterious, disturbing, and unknown. As one young curator put it, 'there are no limitations in thinking here, you can think in every direction'. Another added, 'the older a mind is, the more it categorizes - what is good, what is bad' (Muzeum Narodowe w Warszawie 2016: 249). The curators often developed their own stories and contexts for the objects they encountered, which served to deepen their engagement, appreciation, and sense of connection to the works, seemingly more than a 
singular insistence on 'facts' would have. They also created atmospheric, multi-sensory, and interactive exhibitions that engaged visitors' bodies and senses in dynamic, creative ways not often experienced in traditional art galleries.

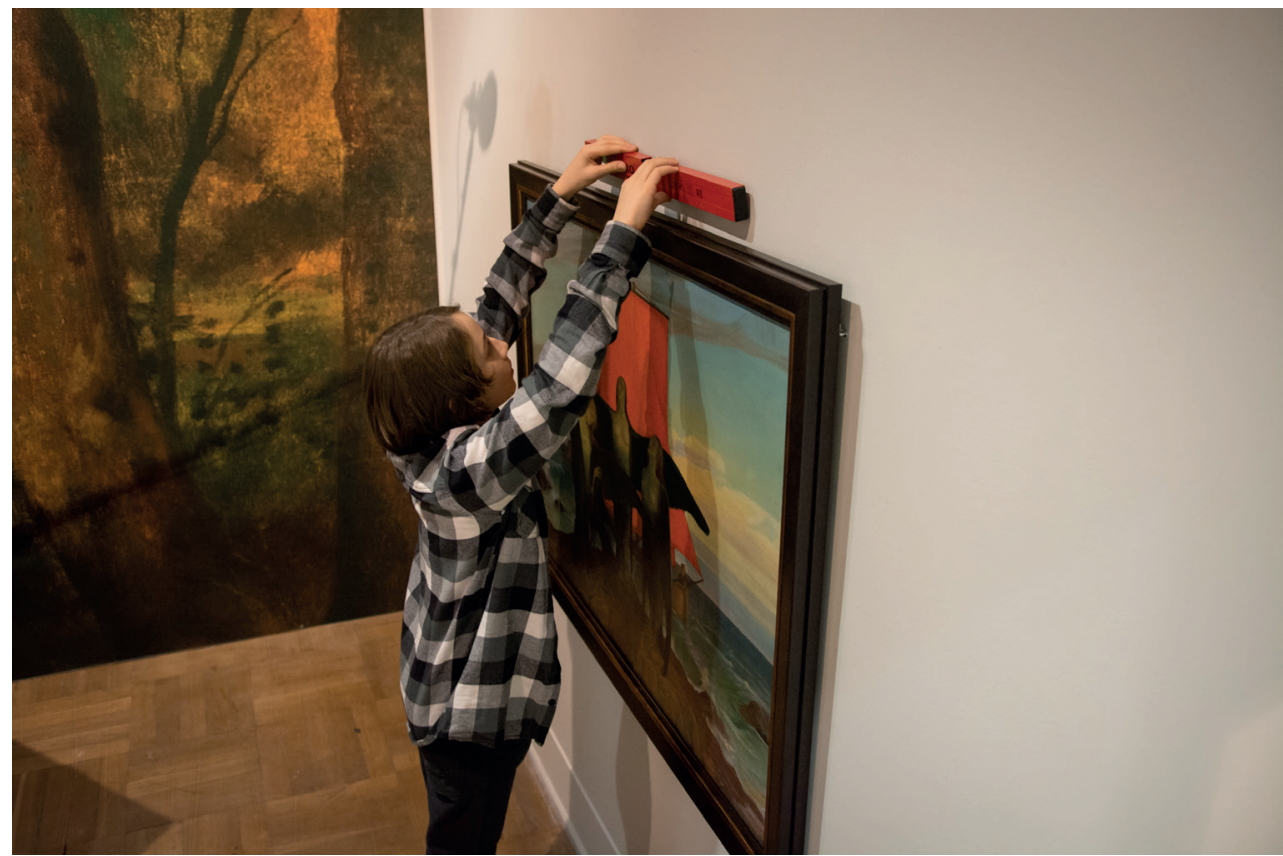

Figure 3: A curator hanging art at children's eye level. Photo: National Museum in Warsaw.

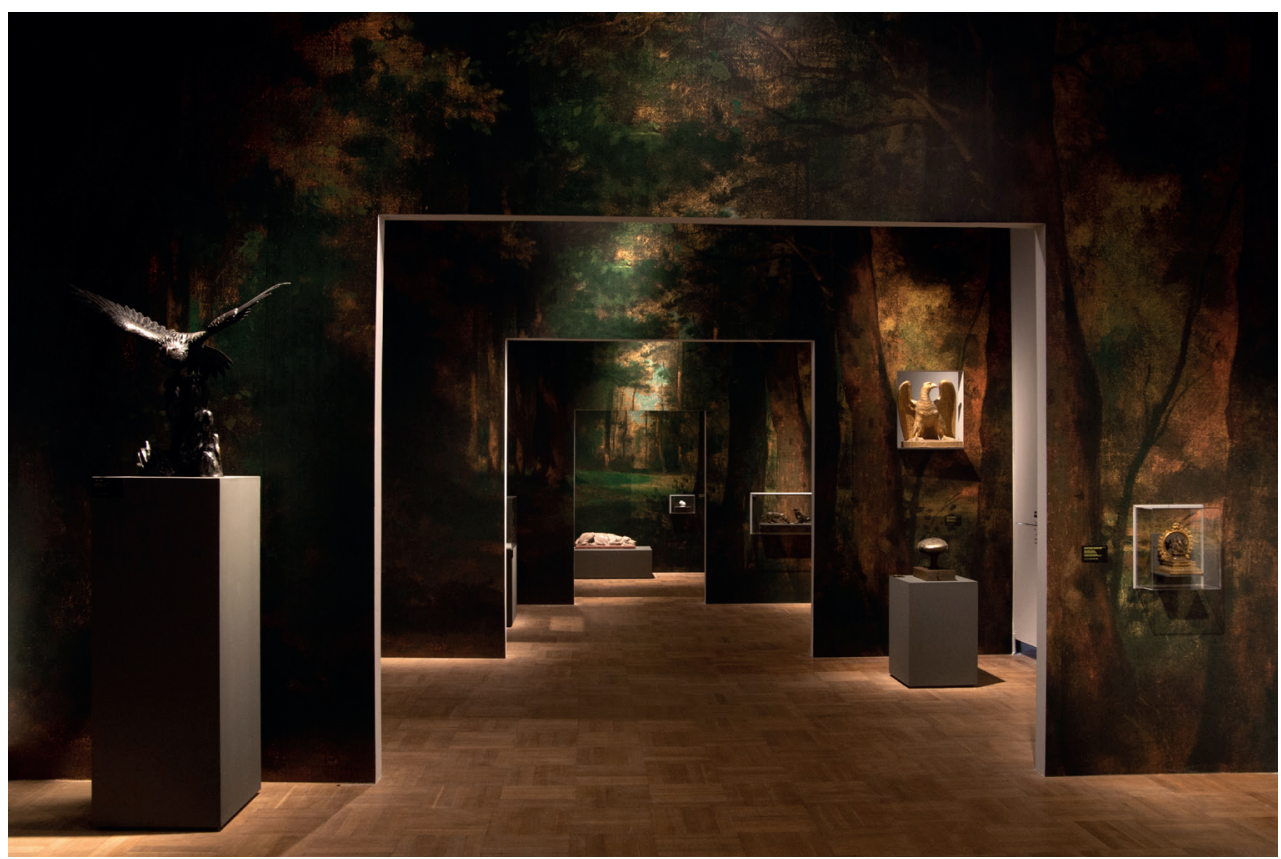

Figure 4: 'A Forest' Gallery. Photo: National Museum in Warsaw. 
In the gallery room titled 'A Forest', the curators began, 'We haven't seen any museum exhibitions about a forest before. That's why we've decided to prepare one ourselves' (Morawińska 2017: 22). ${ }^{12}$ Visitors stepped into an evocative mise-en-scène with dim lighting, ambient birdsong, and floor-to-ceiling prints of a painted dark forest. This backdrop showcased the curators' favourite representations of animals from the museum's collection and explored 'beliefs and stories associated with them', including what humans and animals share; experiences of animal domestication, husbandry, and friendship; and their links to the divine (Morawińska 2017: 22). Artworks - selected by team members through a democratic voting process - were displayed on pedestals and in vitrines, and included sculptures of eagles and a sleeping dog, Egyptian animal mummies, representations of Indian and Mongolian deities, and fantastical creatures such as sirens and harpies. In true dialogic and participatory fashion, the curatorial statement closed with a question that shared curatorial authority with visitors, empowering and encouraging them to make their own connections: 'Can you find any links between Svetovid, an Egyptian mummy, Leon Wyczółkowski's painting, and the dog painted by Olga Boznańska?' (Morawińska 2017: 22).

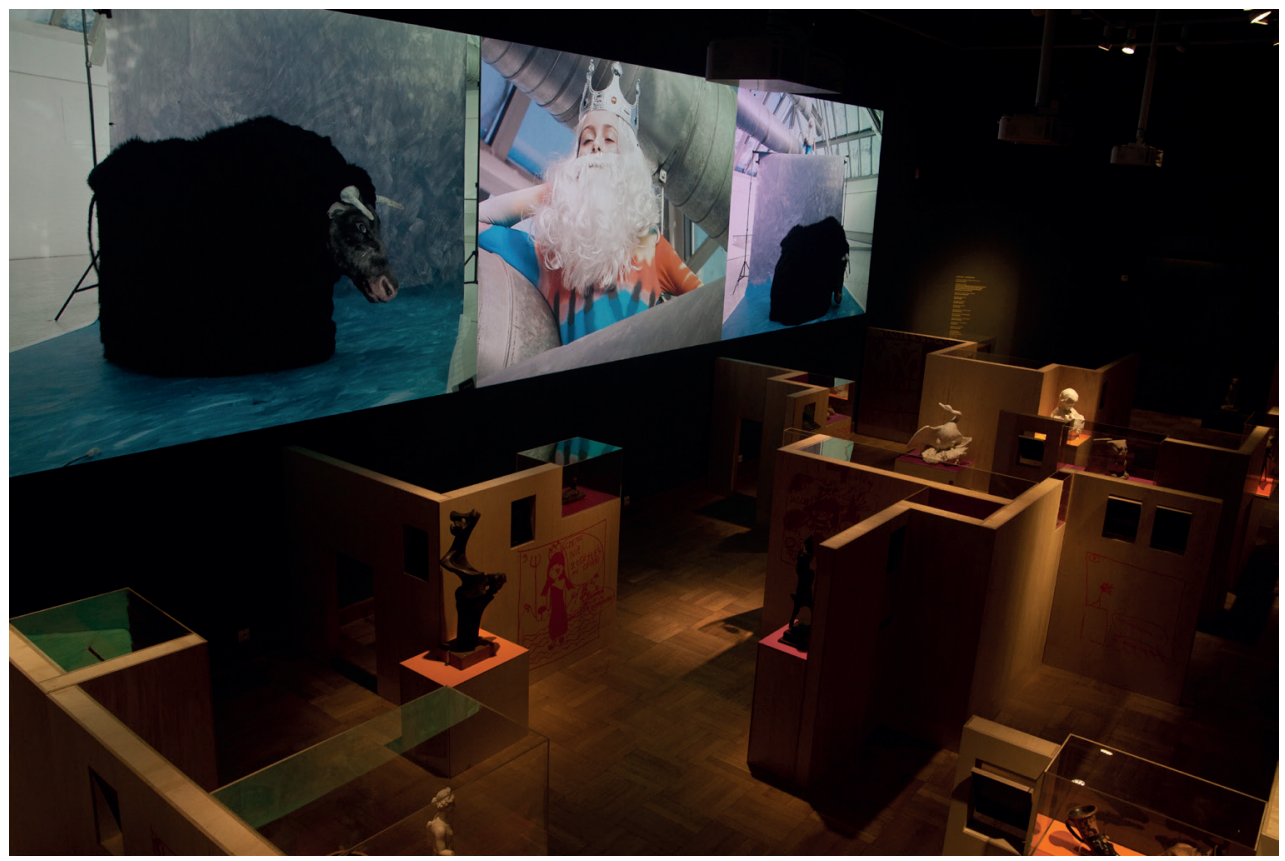

Figure 5: 'Dance of the Minotaur' Gallery. Photo: National Museum in Warsaw.

The next gallery, 'Dance of the Minotaur', extended the animal theme established in 'the Forest', but with an intensified atmosphere of mystery via a multimedia labyrinth motif. Visitors had to navigate a maze of sharp turns and dead ends made of wooden partition walls. Shoulder height for an average adult, the labyrinth contained recessed vitrines and pedestals displaying ancient and contemporary artefacts depicting animals, accompanied by curators' interpretive drawings and text. Young visitors could crawl through child-sized doorways to discover additional hidden items, reversing the usual hierarchy of adult-only content with spaces and objects accessible only to children. The curators urged visitors' imaginative engagement with the space:

When you wander along the corridors of the labyrinth, trying to escape the dangerous beast, you're going to meet a mummy of a ram in a gold-plated case, small hedgehogs turned into dishes, a boar captured by Hercules, a lonely teddybear trapped in a Plexiglas cage, and many more... Have a great adventure in the labyrinth! (Morawińska 2017: 24). 
The highlight of this gallery was a six-minute original film conceived, written by, and starring the curators as actors. ${ }^{13}$ Titled 'The Dance of the Minotaur' (2016), the film reinterprets the mythological story of King Minos, the Minotaur, Theseus, and Ariadne. Co-produced by a professional crew, the young curators designed their own costumes and chose the set locations. It featured three frames projected as a triptych visible to viewers as they navigated the labyrinth structures. The film ran continuously in a loop. Linking past and present, the story opens with menacing music as the Minotaur emerges, marching in time. We learn from a nine-member Greek chorus that King Minos' wife, Queen Pasiphaë, is cursed by King Poseidon to be mother to a terrible Minotaur. The Minotaur is kept in a locked cell inside a labyrinth, but once a year is given a 'special feast' of 'fourteen pure youths [who] are sent to feed the beast'. When hero Theseus comes to end the barbaric practice, he meets King Minos' beautiful daughter Ariadne, who gives him a ball of blue rope to help him find his way out of the labyrinth. Upon meeting in the dark maze, the Minotaur and Theseus engage in a dramatic lightsaber fight with futuristic sound effects. Theseus emerges victorious after decapitating the monster, who falls to the ground with a feral groan, and is circled by the members of the chorus before the film cuts to the final credits.

The film and gallery are unique and avant-garde contributions that break from traditional museum protocol in several ways, while providing attentive viewers with a deeper view into the meanings, desires, and worldviews of (some) children. Unconstrained by traditional art historical frameworks that emphasize historical periods and geographies, the curators were initially inspired by a plate with a bull's head made by Picasso (Kielczewska and Pysiewicz 2016: 244). As curator-playwright-actors, they used the classic form of the Greek tragedy to juxtapose ancient elements such as mythological figures and a chorus with contemporary features such as lightsabers and a television. Cutting across time and place, this assemblage creates an evocative aesthetic and affective range using music, sound effects, lighting, miseen-scène, dialogue, and plot to produce a valuable new work of art itself.

While children are often perceived as particularly vulnerable and therefore shielded from disturbing or violent material in museums and art galleries, these children engaged with such material boldly and directly, creating a physical, multi-media environment containing hidden, adult-free spaces where children could experience fear and mystery with independence. Significantly, setting the film in the museum's attic, technical workshops, and basement gave visitors virtual access to exclusive museum spaces. In so doing, the curators pushed back against the museum's institutional authority and used their new power to increase public access by inviting visitors into the museum's most privileged spaces.

While the 'Dance of the Minotaur' gallery created an opportunity for visitors to play with fear, the 'The Ghost Room' attempted to scare visitors outright. In their opening statement, the curators wrote that:

Having visited the contemporary painting storeroom and discovered Zdzisław Beksiński's painting of a "Rotting Zombie", [Obraz VIII (Zen)], we began to look for terrifying works of art in other places too. Surprisingly, it turned out that there's no shortage of them in the museum (Morawińska 2017: 26).

Taking a cue from the artworks, the curators 'also relie[d] on light and sound to create the appropriate atmosphere' (Morawińska 2017: 26). They too developed a narrative frame for their gallery, which demanded that visitors take on an active role as they made their way through the frightening space. Visitors were informed that they were exploring the lair of a mad English doctor and his collection of scary objects (including representations of séances, cemeteries, skulls, tombs, and mysterious landscapes with ghosts and circling vultures), and tasked with deciphering encrypted captions accompanying several works to learn more about the 'adventures of our haunted hero' (Morawińska 2017: 26).

Working with adult designers, the curators created a multi-sensory, interactive exhibition within an unnerving motion-animated forest projection. Black silhouettes of large birds perched on the frames of select artworks. When visitors approached, they squawked loudly, flapped their wings, and flew away. The room was dim and the walls were painted dark grey. Eerie blue lights shone through the eye sockets of several skull sculptures, and an old black Bakelite telephone rang loudly. A few pieces of decrepit furniture were installed on specially-built sloping platforms at odd angles, adding to the theme of darkness and decay. 


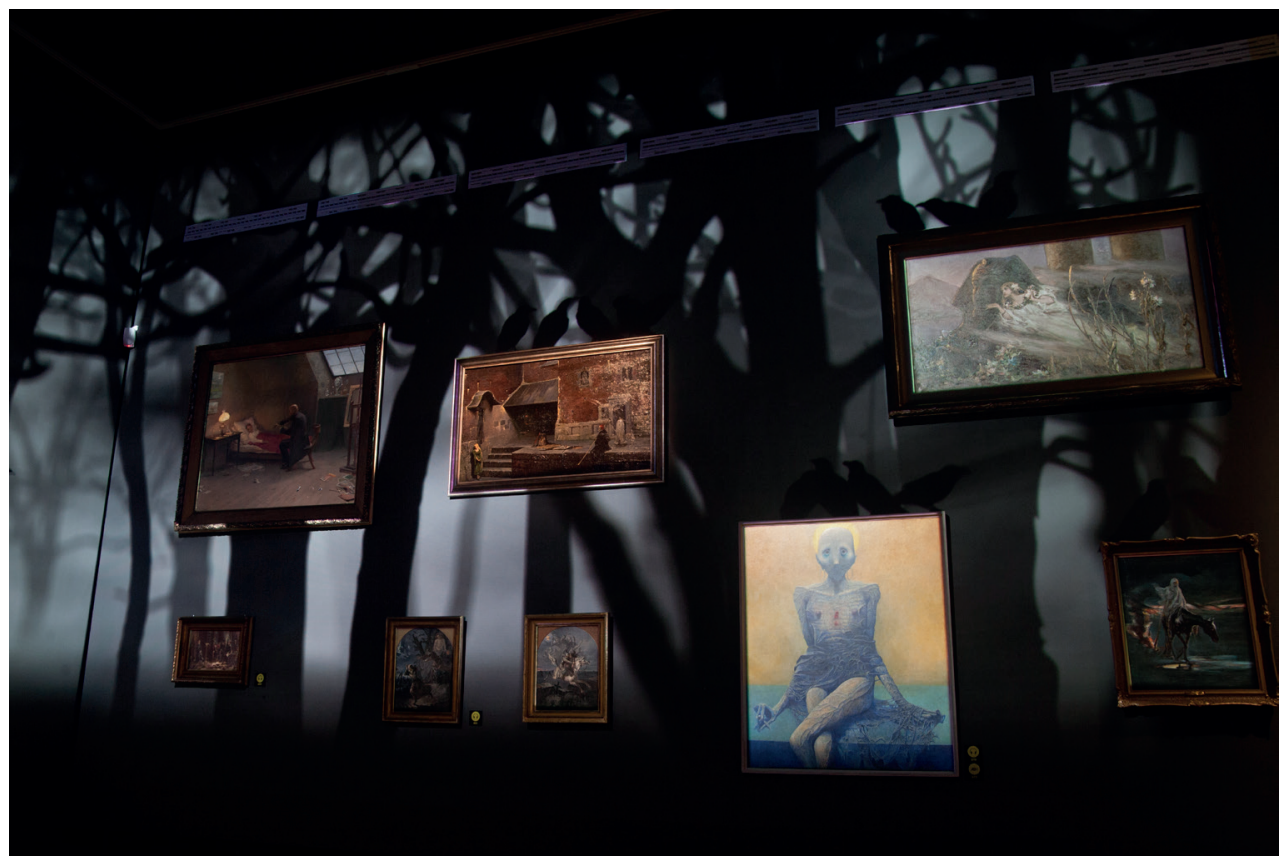

Figure 6: 'The Ghost Room' Gallery. Photo: National Museum in Warsaw.

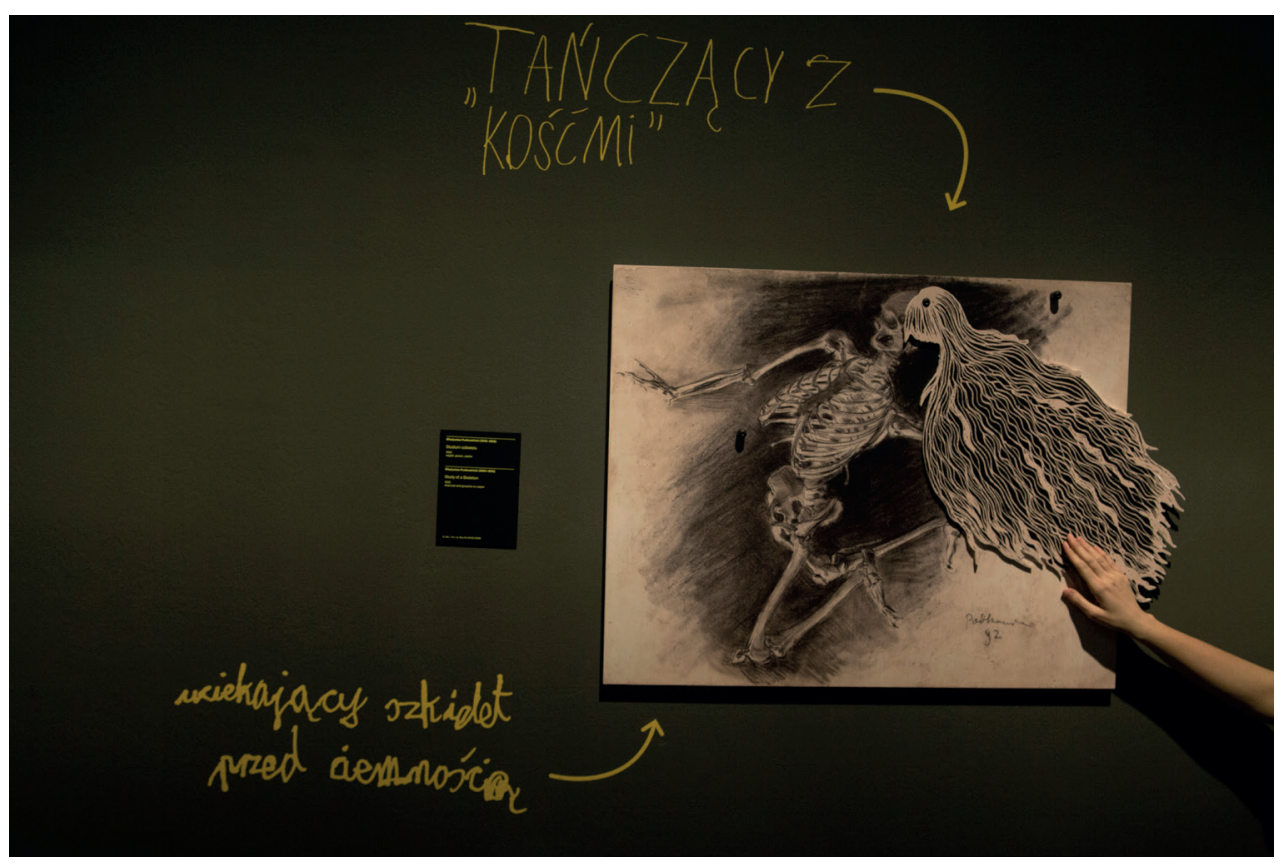

Figure 7: Manipulable PVC cover over print of Władysław Podkowiński's Studium Szkieletu (1892), coal and gouache on paper, National Museum in Warsaw. Photo: National Museum in Warsaw. 
If the curators wanted to give visitors a good scare, they also wanted to help them conquer their fears, leaving them braver at the exhibition's end. ${ }^{14}$ Visitors could thus determine the extent of their engagement with disturbing materials. For instance, if they answered the ringing telephone, visitors heard a series of terrifying sounds recorded by the curators. Similarly, they could choose to lift PVC reproductions of macabre prints to reveal even more disturbing images below [see Figure 7]. In creatively accommodating different comfort levels, the curators shared their authority, and as hosts recognized that not only children may have sensitivities requiring accommodation.

After confronting fearful objects in 'The Ghost Room', visitors ventured into the 'Playing the Hero' gallery to explore the question of what makes a hero. The curators explained: 'our imaginations were most stirred by stories of colourful historical personalities documented in works of art. We wanted to talk about heroism'. The exhibition featured 32 heroes, including historical figures such as Albert Einstein, Napoleon, and King Alexander the Great; military leaders such as eastern samurai warriors and Polish statesman Józef Piłsudski; religious figures including saints and Jesus Christ; the mythological figure of a golden dragon; everyday heroes such as firefighters, construction workers, and girl scouts; and two anti-heroes: a toreador killing a bull in an unequal fight (Francisco de Goya's Manly courage of the celebrated Pajuelera in the ring at Saragossa, plate 22 from The Art of Bullfighting, 1816) and Miss Polonia, the 1920s Polish beauty queen who refused to give up her throne.

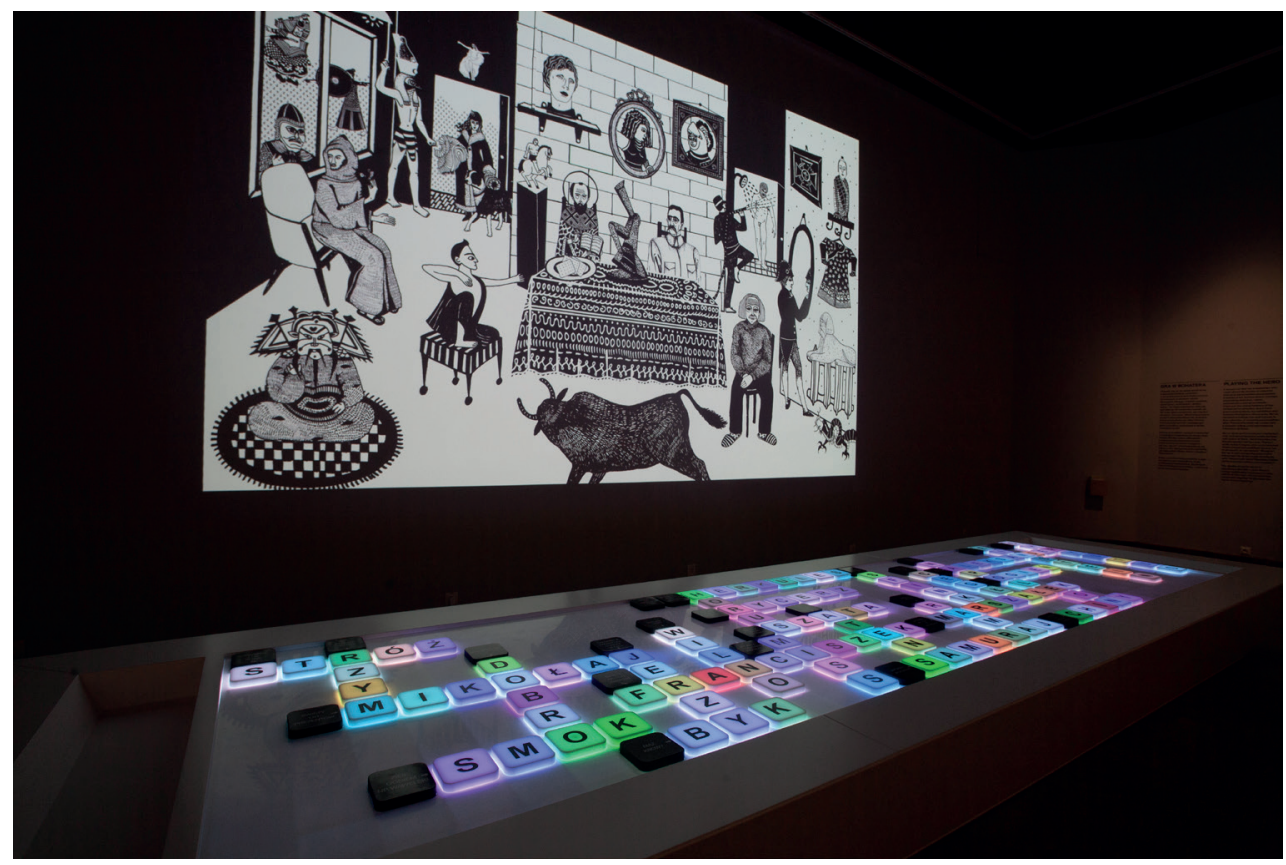

Figure 8: Interactive crossword puzzle with activated animation in the 'Playing the Hero' Gallery. Photo: National Museum in Warsaw.

A six-metre tall multimedia crossword puzzle challenged visitors with riddles to spell out heroes' names who then appeared in a wall animation produced by the curators. Successful completion of the puzzle revealed the exhibition's motto 'Courage'. The crossword was the most costly and complex element of the entire exhibition, and one of its most popular features. The puzzle worked best if several people worked on it together, staging an opportunity for dialogue, cooperation, and participation among multi-generational visitors.

'Treasure Trove' was the most traditional gallery, based on over 50 prized objects made of silver, gold, precious stones, and porcelain from the museum's storerooms. Russian 
jewellery, a Persian carpet, gold Baroque drinking vessels, a china tea set for dolls, and a gilded bronze candelabrum from France were displayed in protective glass vitrines in the low-lit room. A nine-minute film presented the curators' reflections on what makes a treasure..$^{15}$ From friendship and family to rarity of material ('You won't find ham sandwiches here!'), monetary worth, uniqueness, age, care in production ('not like they do in factories'), importance, or being owned by famous persons, 'everyone may have their own definition of what is a treasure'. Highlighting the inherently subjective nature of value, one young curator declared, 'It's enough if someone likes it. It can be very precious to them'.16

The final gallery, 'Changes', explored the fluctuating forms and functions of fashion through the ages and across the globe. Objects ranged from an ancient statue depicting the 'wasps' nest' hairstyle, to clothing and accessories from the communist period, a Rococo tailcoat with jodhpurs, and a Chinese shoe for a bound foot next to a slipper painted by avant-garde master Hanryk Stazewski. To illustrate that our primary and most durable outfit is the skin, Greek vases with naked wrestlers were also featured. The curators explored questions such as: 'Does fashion entail suffering? What did the clothes of ancient sportsmen look like? Was a sword always used to fight? Who was the Polish Dior?' (Morawińska 2017). The curators explored shifting and varying notions of aesthetics, protection, and comfort in addition to gendered aspects of clothing in different times and places.

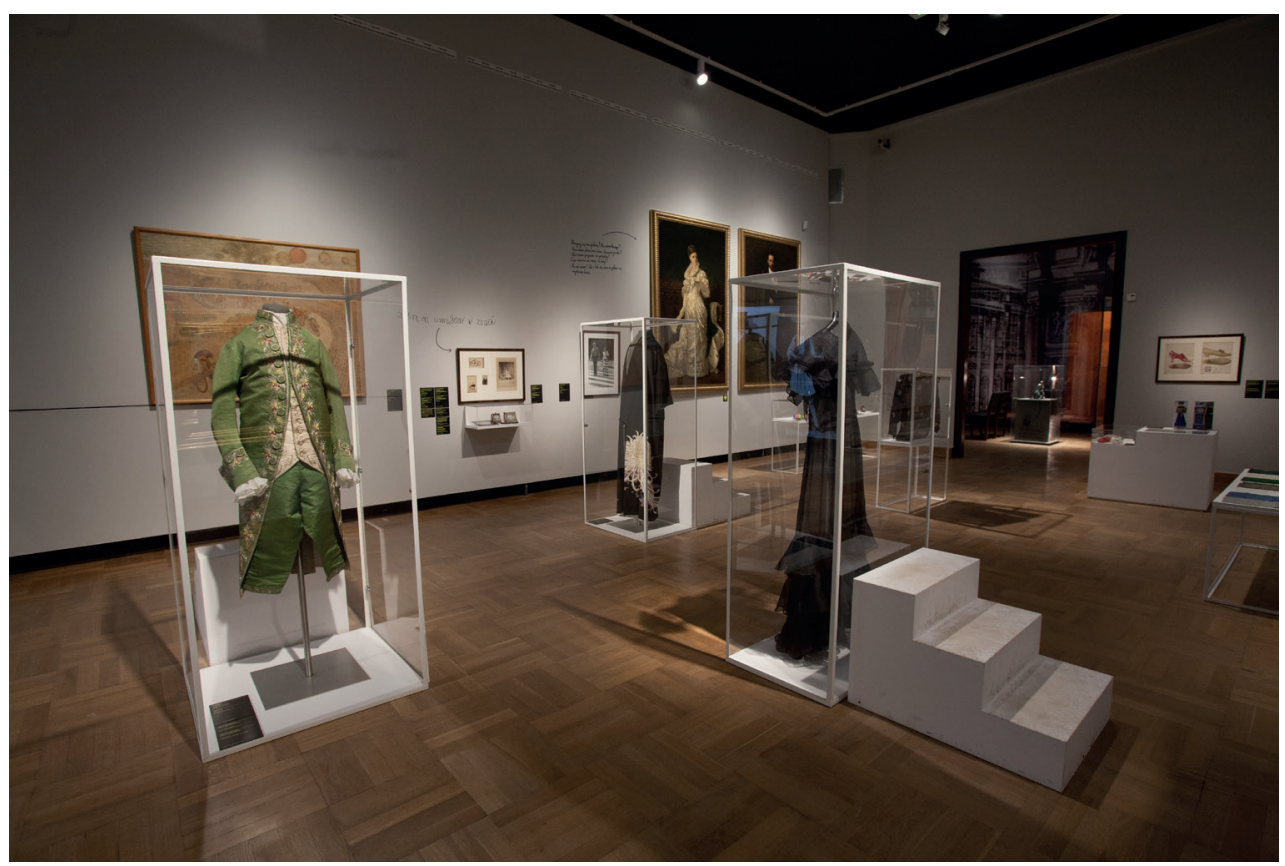

Figure 9: 'Changes' Gallery. Photo: National Museum in Warsaw.

Throughout their process, one of the curators' greatest frustrations was not being able to try on the clothing from the collection. This limitation led to a simple but effective and engaging technological innovation on the part of the curators and designers: five costumes were displayed on metal frames in raised glass cases that could be approached via steps to accommodate various heights. Standing behind the display, visitors could 'try on' costumes without touching them by positioning themselves against the glass cases for a visual 'fitting'. By manipulating sight lines and camera angles, friends or family members on the other side of the protected period pieces could capture companions' new looks with their cell phones. Further visitor interaction was invited through touchable fabric samples and movable figures called 'manipulators' made of stacked wooden blocks with different costumes on each side 
that could be rotated to create various style combinations. Including such opportunities for 'hands-on' encounters with exhibited objects is a popular approach for engaging young people and decentering adult authority in the museum, long utilized by children's museums.

\section{Adult Authority and Child-Centered Museology}

Until the late twentieth century, the study of childhood was dominated by scientific and sociological discourses that viewed children as inherently irrational, incompetent, inferior, and passive, and understood them in terms of what they lacked, what they were not (yet), and in relation to adults, rather than on their own terms (Lancy 2008; Walkerdine 2009). In the last three decades, sociocultural scholars have insisted on the value of children's knowledge and worldviews and the diversity among children in different times and places (e.g., Levine et al. 1994; Montgomery 2009). In presenting their 'New Social Studies of Childhood', James and Prout ([1990] 1997) argued that children must be seen as active in the construction and determination of their own social lives and the societies in which they live. Proponents of this paradigm advocated research with children rather than research on children (James et al. 1998; Jenks 2005). Since then, much has been written about child-centred research (Freeman and Mathison 2009; Clark 2011; Grieg et al. 2013; Frankel 2018). While Anything Goes was not a research project, it is an example of adults learning from and with children, in a child-centred and collaborative way that privileged their knowledge and perspectives. As Clark (2011: 80-1) argues, adults can share their power with children and take their ideas and agendas seriously. This often involves taking risks, enjoying play, and embracing ambiguity and contradiction.

I first heard about Anything Goes in 2016 while visiting Warsaw to give a lecture on children's museology for Laboratorium Muzeum [Museum Lab], a program bringing new, international museum thinking to Polish curators. ${ }^{17}$ I learned all that I could about the exhibition by visiting the National Museum of Warsaw, reading the exhibition catalogues, analyzing press coverage, and interviewing the project's lead educator, Ania Knapek. ${ }^{18}$ The project was premised on the idea that the museum educators would follow the children's lead, as opposed to guiding them (Kielczewska and Pysiewicz 2016: 243). Knapek relayed that the young curators repeatedly said they created the display without adults' help. 'We considered that a success', she said, 'because of course we helped design sets and did other things, but the children did not feel our presence controlling their own work'. The children took great joy in rejecting adults' suggestions. As educators Kielczewska and Pysiewicz (2016: 246) recalled, 'they wanted to be autonomous in their own choices. Many times they would repeat, "we are the decision makers, we are the curators".' They also worked critiques of adults into some of the narrative frameworks they developed for the exhibit, such as the mad collector's 'Ghost Room' and the satirical depictions of the lazy king and corrupt, cruel architect who force a young girl into the Minotaur's cave as a sacrifice ('Dance of the Minotaur').

While the children were given an impressive amount of authority and autonomy, there were also points of collaboration and compromise to navigate. Adults at times imposed limitations that constrained the child curators' vision. For instance, while they strived to let the children lead whenever possible, museum staff would not allow furniture to be suspended upside-down from the ceiling in 'The Ghost Room', nor padlocks on each copy of the Polish exhibition catalogue. Adult staff also vetoed the curators' idea for creating a line of bed sheets with a reproduction of the zombie-like decaying female figure from Zdzisław Beksiński's 1969 oil painting, Obraz VIII (Zen) to sell in the gift shop (Kielczewska and Pysiewicz 2016: 248). While adult curators wrote traditional object labels conveying the artist, title, date, and medium, the children also wrote labels containing imaginative stories and impressions unbound by established facts. Many of the children's labels were reproduced in their handwriting, with their grammar and spelling mistakes, imperfect penmanship, smudges, doodles, and scratched out words. Disparaged by some visitors and critics (e.g., 'a distorted notion of the education of children, how awful!': see Rakoczy 2017: 15), the children's labels offered a unique commentary, beyond the 'linear whole which normally is seen and expected in spaces of temporary, structured artistic organization', and modelling for observers how to be similarly active, self-reflexive, and imaginative (Rakoczy 2017: 15). 


\section{The Exhibition's Reception}

The exhibition was enthusiastically received by the majority of visitors, enjoyed significant media attention, and was recognized with multiple professional accolades..$^{19}$ It was also evaluated by an external professional firm. ${ }^{20}$ It was important to the curators that their exhibition be seen as not just by children for children, but for everyone. They repeatedly expressed their desire to be taken seriously by the public. By and large, they succeeded. One visitor enthused, 'It shows a huge variety of collections of the National Museum. I was without children and I really recommend [this to] adults, not only children!'. ${ }^{21}$ Others were more cynical, insinuating that adults pre-selected the artwork, ${ }^{22}$ or expecting a less constrained setting more like a playground than a museum: 'It turned out that the museum is not allowed to do anything at all, and above all, it is forbidden to touch, rearrange, draw, write on the wall, or skate (this is my objection)'. ${ }^{23}$ For Director Agnieszka Morawińska, the most important thing was that the museum 'not be intimidating, [but] friendly and inviting - not only for children, [but] for all visitors'. ${ }^{24}$

Despite extensive media coverage, visitor turnout was average. Considering the bias against children's cultural production that minimizes its value and relevance to broader publics - particularly in historically elite fields like art history, museology, and curatorial studies - this was a success. In addition to acquiring museological skills, knowledge, and experience, the young curators improved their sense of agency and self-confidence, and developed their negotiation and self-presentation skills, learning to formulate and articulate their opinions among their peers, with adults, and when facing the public (Szostakowska 2017).

Shortly after Anything Goes closed, the MNW organized a seminar on the exhibition and its production process for their colleagues in other institutions. Some were critical, insisting that the project was a form of educational programming rather than an exhibition. This critique reflects institutional hierarchies and broader, deeply entrenched institutional structures and cultural biases that distinguish museums' engagement with children from the curatorial domain, sequestering it instead in education and programming departments that are typically marginalized in relation to exhibition making, and whose members tend to have lower-paid, lower status, temporary positions in relation to their more esteemed colleagues in research, curation, and conservation. Lead educator Ania Knapek shared that she often wonders how the exhibition would have been received if the museum did not publicize that it was created by children. ${ }^{25}$ Overall, evaluators found that MNW employees believed the project brought the institution into conversation with some of the latest curatorial trends in museology and that it raised the museum's prestige. ${ }^{26}$

\section{Strengths and Contributions}

Careful analysis of the Anything Goes exhibition reveals that children have much to contribute towards the goals and principles espoused by 'new' and 'critical museology', particularly in terms of correcting the exclusion and denigration of minority groups from museum collections and representations. By sharing institutional authority with children and giving them the resources, space, and power to represent themselves, the MNW set an important precedent for museums' future considerations and practices of inclusion. The children's own primary goal for their exhibition was to create something of interest to everyone, breaking from the normative practice of catering to either children or adults. ${ }^{27}$ The young curators drew from their own knowledge, experience, creativity, and inventiveness to create many new exhibition technologies and narrative frameworks to present the works of art they chose to display, many of which had never been exhibited. Their curatorial approaches often defied existing categorization: not solely (art) historical, personal, or fantastical, the curators blended these, adding elements of mystery, historical fiction, personal growth, and play to challenge canonical assumptions about what is valuable, worth showing, and why. They used creative, multisensory technologies and strategies to strengthen museum-visitor relationships, as most of the galleries required audiences to actively negotiate the exhibition in various ways, engaging their bodies, minds, emotions, and senses.

Much has been written about the benefits of catalyzing dialogue and interaction in museums (Simon 2010), and curators are stepping away from the traditional single-voice 
didacticism that tells visitors how and what to think, in favour of more open-ended prompts to self-reflection and interpersonal communication (Karp and Kratz 2015). The Anything Goes project was itself an extended conversation among children, their parents, tutors, and MNW employees. ${ }^{28}$ The curatorial teams employed democratic processes, and in a particularly radical innovation, the young curators insisted on soliciting input from the gallery guards, a typically unrecognized demographic in museums, let alone one asked to be involved in exhibition production. It is striking that in claiming space and voice for themselves, the children also sought to share their newfound power with their visitors and to disperse it more equitably across the institution's staff.

The curators emphasized the importance of process by providing visitors with rare glimpses into the backrooms and planning stages of their exhibition development work. Such transparency is typically lacking, as museums tend to present polished finished products that conceal important debates and dilemmas that went into their production. As many scholars have argued, the process of working through these hidden challenges can be more insightful and instructive than the final exhibition itself (Young 1994; Linenthal 2001; Lehrer et al. 2011). The curators also shared their experience with the Polish public via media interviews, gallery tours, and personal reflections on specific artworks and the curatorial process in the exhibition's accompanying audio guide.

Many of the curators saw their role as liberatory. In their writings and interviews there was a recurring motif of the museum storeroom as a prison for objects (Morawińska 2017: 30): 'Freed from the archives, the works acted as pretexts to creating individual worlds, [and] certain atmospheres' (Kielczewska and Pysiewicz 2016: 246). Through their imaginations and curatorial innovations, the children liberated the objects not just physically, but also from singular and didactic readings, meanings, histories, and interpretations.

The curators' democratizing efforts were not limited to the exhibition production process, however: they impacted the MNW in lasting ways that have led to real institutional change. As Director Agnieszka Morawińska explained, preparing the exhibition taught the staff many things, including

that we must strive to change [our] language [when] we are talking about art. The information we provide is very often incomprehensible to many... We must get to the viewer without "historical-artificial" jargon. The children's project also confirmed... that very different arrangements of objects are possible, that you can look at them at a very different angle, take into account various stories that [are] reveal[ed] through them. The museum turns out to be a place where this mosaic can be arranged differently. Everyone can do it. ${ }^{29}$

The transformation was also lauded on the Sybilla Award website, which described the project as one in which 'everyone had to break some sort of habit: stereotypical perception, obsessive classification, routine working methods [within the museum space]'. ${ }^{30}$ Lead educator Ania Knapek noted the many ways that MNW's institutional boundaries were breached as a result of the exhibition. As an educator, she never had the opportunity to curate, or even to be involved in the early stages of the exhibition production process. For curators, an exhibition opening signals the end of their work on a project, while for educators it marks the beginning. As Villeneuve and Love (2017) have noted, such a division is typical as art museum educators rarely engage with curators to help conceptualize exhibitions or develop content. Indeed, programming is often developed independently, after exhibition design is completed, all but ensuring that children's interests and concerns are both an afterthought and beyond the range of influence that other marginalized communities increasingly enjoy. If children's museums do better at integrating child-centered efforts across the institution and the process of exhibition development (Judd and Kracht 1997; Mayfield 2005), children are still rarely involved in the curatorial process (Mallos 2012). Knapek also relayed that many MNW curators said it was the first time they had a chance to meet everyday museum visitors. She felt she learned a lot from the children, and saw how important it is to work with them at all stages of exhibition planning and design. ${ }^{31}$

The exhibition's affective power was another source of strength. As Kielczewska and Pysiewicz (2016: 243) recalled, the curators wanted to 'not only tell stories, but above all to 
evoke emotions, "infect with feelings", and draw visitors into a museum game... that will not allow passivity'. In their unique drawings and labels, films, and audio guide, the curators shared their own emotional connections with the objects. Going through Anything Goes, visitors were prompted to a much broader range of emotions than are typical for an art museum: alongside the usual wonder, curiosity, admiration, and joy, one might experience fear, pride, and accomplishment.

Observing the overwhelming homogeneity of children's museums across the world, Kathie Carpenter (2019: 2) notes that predominant design principles are 'based on assumptions about what attracts and excites children, rather than what might calm them or help them appreciate other aesthetics', resulting in a homogenous 'focus on the self, along with bright colors and cartoon-like images of animals, especially pets and dinosaurs'. Attention to the range of responses the curators sought helps us understand children's interests and subverts commonly held, stereotypical assumptions about their capacities for engaging with difficult and disturbing content. While museums often constrain children's access to difficult material through recommended age limits, physical barriers, and otherwise sequestered content, these young curators were often drawn to gruesome and even frightening works in the collection, and eager to tackle scary and unsettling topics like death and monstrosity.

\section{Challenges and Limitations}

Anything Goes broke many precedents in terms of its scale, scope, budget, innovations, and level of institutional commitment to an experimental exhibition professionally curated by children. Yet despite its many strengths, the show also had its limitations. Due to variations in the curatorial teams' dynamics, skills, and interests, some of the gallery rooms were less coherent and creative than others, and the absence of an overarching theme to cogently unite the different rooms was a missed opportunity for broader narratives. The project also strained institutional resources in some ways, demanding extra time and energy (particularly weekend hours) of staff.

The gallery guards faced particular challenges from unruly visitors who expected to be able to do whatever they liked in the exhibition, including touching the displays. At the beginning of the project, the young curators were often frustrated that their access and power to explore the museum collections was not absolute. Through the weekly workshops, however, as they learned about the fragility and uniqueness of different objects, gained skills in handling artworks carefully, and were able to touch some artwork wearing gloves, they came to appreciate the 'don't touch' rule and even went on to enforce it themselves. But touching became a source of tension and frustration again after the exhibition opened. Many of the adults and children who visited the exhibition thought that since it was made by children, they would be allowed to touch anything. This message was unfortunately reinforced in the exhibition's Polish title, W Muzeum wszystko wolno, which literally means 'In the museum everything is allowed'. ${ }^{32}$ While the curators built in many opportunities to touch, guards struggled to keep visitors from touching things that were off limits. As Kielczewska and Pysiewicz (2016: 245) recall,

The first two days of the exhibition opening proved to be a lesson in humility, during which some of the invited parents took the title of the show literally and came to the museum as if they were going to one giant playground. There was no clear information about what was and was not allowed. Only a few works invited visitors to interact with them, while the others could not be touched. The exhibit guards had to be alert and reprimand eager viewers who wanted to touch everything. Therefore, right after the vernissage, the decision was made to add special hand signs pointing to which objects could be touched... [and] the curators wrote guidelines on how to visit their shows.

Another limitation of the project was the homogeneity of the participant group, with most of its members coming from middle- to upper-class, well-educated families who were already regular visitors to the MNW, and conversant in basic museum literacy. Indeed, many of the participants' parents worked at the museum or in the arts and culture field more broadly, an effect of the museum's narrow channels for recruitment. ${ }^{33}$ While the relative privilege of many of the participants probably helped some aspects of the project to run more smoothly, it also 
missed an opportunity to share and reap the benefits of engaging a more varied group of children. Clearly, a first-come, first-served open call on Facebook and within existing museum networks is not an adequate strategy for diversifying participants, and reinforces the echo chamber of those who already exert disproportionate influence on museum programming, since many museum professionals come from these groups (Carpenter 2019: 2).

The number of participants was seen as a limitation as well; but for divergent reasons. While some members of the public criticized the small size of the cohort of curators, the MNW struggled to find space for the 69 children in six curatorial teams to do their work. The decision to organize the children into groups of varying ages had mixed results. On the one hand, it created opportunities for older and younger children to interact with and learn alongside one another, which does not happen often in the school context where children spend most of their time among peers of the same age. In her survey of children's museums across the world, Kathie Carpenter has noted their tendency 'to prioritize developmental appropriateness as a way to facilitate learning, so that exhibitions target an increasingly narrow age range, rather than, say, emphasizing ways that children of all ages can learn together or learn to socialize with one another' (Carpenter 2019: 3). Breaking from this trend, the MNW educators purposefully chose to divide their participants into six groups of mixed ages. This resulted in a general parity across the different groups. On the other hand, a certain degree of ageism prevailed within the curatorial teams which inhibited the younger children and saw older curators exerting more influence. ${ }^{34}$ If the groups had consisted of only older children, more time could have been spent refining and developing ideas at a more sophisticated level, but the unique contributions of younger children would have been lost.

The successes and limitations of Anything Goes offer fertile ground for considering how an emergent 'Critical Children's Museology' might move forward, grounded in critique of the adult-dominated status quo and engaging with children as valued social actors and knowledge-bearers. ${ }^{35}$ Such work must ask: How can museums counteract the reproduction of privilege that brings some children to museums and produces uneven levels of 'museum literacy' across social sectors? How might they help redress the differential benefits that accrue as a result of place of residence, quality of education, economic conditions, and parents' level of involvement, education, income, social status, and other forms of cultural capital? How can future child-centred projects best balance the desire for high production value and children's autonomy and independence?

When asked about the replicability of Anything Goes in other contexts and scales, Ania Knapek replied that a child-curated exhibition could definitely be done with fewer children, on a shorter timeline, and in a single gallery. She suggested that a group of 10-12 children working on one subject could produce something really worthwhile. ${ }^{36}$ Lower income, racialized, neuro-diverse, and disabled children would require approaches that recognized and engaged their unique strengths, needs, and contributions. A fully critical children's museology must actively seek out and engage with participants unfamiliar with museums, and disadvantaged in relation to their current configurations (including their representation or lack thereof in core collections and museum staff). Diversifying museum exhibits, expanding programming, partnering with schools, and building community collaborations would help, but ultimately, if board and staff members don't better reflect the demographics they are meant to serve, true transformation will continue to be forestalled.

\section{Conclusion}

Museums want to be more popular: more engaging, creative, innovative, dynamic, dialogic, intergenerational, and playful (Lorente 2015). But they also want to maintain traditional values: inciting wonder and amazement, educating, and (as in the case of the MNW), honouring national patrimony. In this article, I have argued that engaging with children as active participants and producers of culture, specifically as curators, yields more dynamic, engaging, and innovative exhibition content, programming, and curatorial techniques. The Anything Goes exhibition at the National Museum in Warsaw introduces child-centric approaches central to the field of Child Studies into Curatorial and Museum Studies. Such child-centred praxis is required for an overdue 'Critical Children's Museology' to emerge. 


\section{Acknowledgements}

I would like to thank Ania Knapek for so generously sharing her experience and knowledge of Anything Goes with me, Anna Paluch for providing research assistance and translations of Polish text, Erica Lehrer for her helpful comments on an earlier version of this paper, and the anonymous reviewers for their feedback.

\section{Notes}

1 Monica Eileen Patterson, 'Children's Museology and the COVID-19 Crisis', American Alliance of Museums 18 September 2020. https://www.aam-us.org/2020/09/18/childrensmuseology-and-the-covid-19-crisis/, accessed 16 August 2021.

2 Index Mundi, 'Poland Demographics Profile'. https://www.indexmundi.com/poland/ demographics profile.html, accessed 16 August 2021.

3 Muzeum Narodowe w Warszawie, 'About the museum'. http://www.mnw.art.pl/en/aboutthe-museum/, accessed 16 August 2021.

4 Morawińska served as MNW's director (2010-2018), as director of the Zachęta National Gallery of Art (2001-2010), and as Polish Ambassador to Australia (1993-1997).

5 Children in school groups make up approximately 30 per cent of the MNW's total annual audiences. In 2018, the museum received 350,000 people. (Ania Knapek, interview by author, in person, 7 December 2018, National Museum in Warsaw).

6 Muzeum Narodowe w Warszawie, 'The "Anything Goes" Museum. Exhibition Curated by Children'. http://www.mnw.art.pl/en/temporary-exhibitions/the-anything-goes-museumexhibition-curated-by-children,18.html, accessed 16 August 2021.

7 The Education Department consists of ten full time employees who run all programming, 50 educators paid per lesson or workshop they run, and 90 volunteers. The department hosts 30-40 school groups a day (Ania Knapek, interview, 7 December 2018).

8 Ania Knapek, Educational Programmes Coordinator, Muzeum Narodowe w Warszawie, personal communication, 7 August 2019.

9 The documentary, which is not currently available online, was screened in May 2017 at a special celebratory meeting for the young curators (Knapek, personal communication, 21 August 2019).

10 Muzeum Narodowe w Warszawie, 'The "Anything Goes" Museum'. Exhibition Curated by Children'. http://www.mnw.art.pl/en/temporary-exhibitions/the-anything-goes-museumexhibition-curated-by-children,18.html, accessed 16 August 2021.

11 Posters included the exhibition title, museum location, sponsors, and quotes and drawings by child curators, such as, 'There will be lots of golden objects in our exhibition - Nel (12 years old)'; 'Once there was a tiger, who met a snake, and the snake froze and was taken to the National Museum - Milena (9 years old)'; 'There will be showcases everywhere! And lots of animals! It will be great! - Julka (8 years old), Blanka (9 years old), and Jan (8 years old)'. See: https://mir-s3-cdn-cf.behance.net/project modules/1400/35f49d49455471.58b57417e7378.jpg, accessed 31 August 2021.

12 This and subsequent excerpts are taken from the curatorial statements of each gallery that were created by the curators and republished in the English catalogue (Morawińska 2017).

13 Available at https://www.youtube.com/watch?v=dH2Wxf3LuAl, accessed 1 September 2019. 
Ania Knapek, interview, 7 December 2018.

15

Available at https://www.youtube.com/watch?v=2hoxcxz-FMA, accessed 1 September 2019.

See https://www.youtube.com/watch?v=2hoxcxz-FMA, accessed 1 September 2019.

17 See: http://laboratoriummuzeum.pl/, accessed 1 September 2019.

18 I was not involved in the project itself in any way.

19 The project received the most prestigious award in Polish museology, the SYBILLA Grand Prix award for the most spectacular project of 2016. This was the first time a project in the 'Education' category won the Grand Prix. Anything Goes was also awarded first prize in the 'museums and artistic institutions' category of the Warsaw Prize for Cultural Education (Warszawska Nagroda Edukacji Kulturalnej), the O! Lśnienia prize in the 'exhibition' category, and was shortlisted for the Hands On! International Association of Children in Museums award. In addition, the publishing house that worked in partnership with the exhibition received an award in the Competition for the Editorial Book of Excellence 'Edycja' in the 'Event' category.

20 Project organizers, young curators and their parents, tutors working with the curators, museum employees, and visitors to the exhibition were evaluated using a range of individual and group interviews, observation, and questionnaires. According to the evaluators, the main successes of the project included the professional preparation of the exhibition and programming with considerable participation of children, high and consistent attendance of the participants, activation of the children's parents (an unplanned benefit), challenge, growth, and enhanced creativity experienced by MNW Education department employees, changed thinking among MNW employees more broadly (particularly in regard to developing creative solutions to challenges posed by the curators), and significant media interest in the exhibition.

The full text of the report, in Polish, is available on the website of the MNW here: http://www. mnw.art.pl/gfx/muzeumnarodowe/userfiles/ public/ewaluacja projektu w muzeum wszystko wolno raport.pdf, accessed 31 August 2021. A synopsis of the findings may be found in Szostakowska 2017.

21 Guest, in comments section of Monika Rozpędek, "W Muzeum Wszystko Wolno'. Kustosz: Tylko nie Dotykać! ["Anything Goes in the Museum." Curator: But don't Touch!] WawaLove 11 April 2016. https://wawalove.wp.pl/w-muzeum-wszystko-wolno-kustosz-tylko-niedotykac-6178744799004289a, accessed 16 August 2021.

22 Rozpędek, 'W Muzeum Wszystko Wolno'.

23 Katarzyna Kasia, 'Czego w Galerii Jednak nie Wolno. O Wystawie „W Muzeum Wszystko Wolno" w Muzeum Narodowym w Warszawie [What isn't Allowed in a Museum. On the exhibition "Anything Goes Museum" at the National Museum in Warsaw]', Kultura Liberalna, 3 May 2016. https://kulturaliberalna.pl/2016/05/03/czego-w-galerii-jednak-nie-wolno-owystawie-w-muzeum-wszystko-wolnol, accessed 30 August 2021.

24 Agnieszka Morawińska and Katarzyna Kaczmarek, 'W Muzeum Wszystko Wolno [The Anything Goes Museum]', Muzealnictwo 2016. http://muzealnictwo.com/2016/03/wmuzeum-wszystko-wolnol, accessed 16 August 2021.

Ania Knapek, interview, 7 December 2018.

26 See Note 21. 
27 It should be noted that family-based learning is a rapidly growing area of academic interest and museological practice. See Ellenbogen et al. 2004, Povis and Elizabeth 2016, and Wood et al. 2016.

28 Museum staff began working on the project almost six months before the child curators were brought in, however.

Morawińska and Kaczmarek, 'W Muzeum Wszystko Wolno'.

30 Sybilla, 'W Muzeum Wszystko Wolno Muzeum Narodowe w Warszawie [Anything Goes at the National Museum in Warsaw]', 2016. http://konkurssybilla.nimoz.pl/MNW2016, accessed 31 August 2021.

31 The importance of involving constituent community members from the beginning of exhibition planning to the end of the curatorial process, the exhibition opening, and subsequent programming is a lesson that keeps getting relearned in the aftermath of various exhibition controversies, from Harlem on my Mind: Cultural Capital of Black America, 1900-1968 (1969) to The Spirit Sings (1988) to Into the Heart of Africa (1989) to Miscast: Negotiating Khoisan History and Material Culture (1996) to Indigenous Australia: Enduring Civilisation (2015) to Worlds Within: Mimbres Pottery of the Ancient Southwest (2019), and many others. See, for example, Karp et al. 1992; Watson 2007.

32 As Katarzyna Kasia wrote in her review of the exhibition, 'I experienced the first disappointment when buying tickets, when the lady at the cash desk gently pointed out to me that the title of the exhibition does not reflect reality', Kasia, 'Czego w Galerii Jednak nie Wolno'.

33 Ania Knapek, interview, 7 December 2018.

34 Magdalena Szostakowska and Iwona Pogoda, 'Ewaluacja projektu “W Muzeum wszystko wolno": Raport', Ośrodek Ewaluacji n.d., 28. https://www.mnw.art.pl/gfx/muzeumnarodowe/ userfiles/ public/oe raport mnw 15.06 ostateczny.pdf, accessed 3 September 2021. The widespread choice of the children to rely on democratic voting procedures to make decisions helped mitigate the dominance of older children to some degree.

Patterson, 'Children's Museology and the COVID-19 Crisis'.

36 Ania Knapek, interview, 7 December 2018.

\section{References}

Assembly of First Nations and The Canadian Museums Association (1994) Task Force Report on Museums and First Peoples, Ottawa. https://museums.in1touch.org/ uploaded/web/docs/Task_Force Report_1994.pdf.

Brookshaw, S. (2009) 'The Material Culture of Children and Childhood: Understanding Childhood Objects in the Museum Context', Journal of Material Culture, 14 (3) 36583. doi:10.1177/1359183509106425.

(2016) 'Personalisation and Playlore: Intangible Cultural Heritage and Childhood History in Museums', The International Journal of the Inclusive Museum, 10 (2) 1-10. doi:10.18848/1835-2014/CGP/v10i02/1-10.

Butler, S. (2008) Contested Representations: Revisiting into the Heart of Africa, Peterborough, Ont: Broadview Press. 
Carpenter, K. (2019) 'Finding Place and Feeling Culture in the Universalized Spaces of Children's Museums', The International Journal of the Inclusive Museum, 12 (3) 1-14. doi:10.18848/1835-2014/CGP/v12i03/1-14.

Clark, C.D. (2011) In a Younger Voice: Doing Child-Centered Qualitative Research, New York: Oxford University Press.

Cooks, B. (2011) Exhibiting Blackness: African Americans and the American Art Museum, Amherst and Boston: University of Massachusetts Press.

Ellenbogen, K.M., Luke, J.J. and Dierking, L.D. (2004) 'Family Learning Research in Museums: An Emerging Disciplinary Matrix?', Science Education, 88 (S1) S48-S58. doi:10.1002/sce.20015.

Frankel, S. (2018) Giving Children a Voice: A Step-by-Step Guide to Promoting Childcentred Practice, London: Jessica Kingsley Publishers.

Freeman, M., and Mathison, S. (2009) Researching Children's Experiences, New York: Guilford Press.

Greig, A., Taylor, J. and MacKay, T. (2013) Doing Research with Children: A Practical Guide (3rd ed.), Los Angeles: SAGE.

Hooper-Greenhill, E. (2000) Museums and the Interpretation of Visual Culture, London and New York: Routledge.

James, A. and Prout, A. (eds) ([1990] 1997) Constructing and Reconstructing Childhood: Contemporary Issues in the Sociological Study of Childhood, London: Routledge.

James, A., Jenks, C. and Prout, A. (1998) Theorizing Childhood, Cambridge: Polity Press in association with Blackwell Publishers Ltd.

Janes, R. and Sandell, R. (2019) Museum Activism, New York: Routledge.

Jenks, C. (2005) Childhood (2nd ed.), London: Routledge.

Judd, M.K. and Kracht, J.B. (1997) 'The World at Their Fingertips: Children in Museums', in Barbara Hatcher and Shirley S. Beck (eds) Learning Opportunities Beyond School, 18-24, Onley, MD: Association of Childhood Education International.

Karp, I. and Kratz, C. (2015) 'The Interrogative Museum', in Raymond A. Silverman (ed) Museum as Process: Translating Local and Global Knowledges, 279-98, London: Routledge.

Karp, I. and Lavine, S. (eds) (1991) Exhibiting Cultures: The Poetics and Politics of Museum Display, Washington: Smithsonian Institution Press.

Karp, I., Kreamer, C.M. and Lavine, S.D. (eds) (1992) Museums and Communities: The Politics of Public Culture, Washington: Smithsonian Institution Press.

Kielczewska, A. and Pysiewicz, B. (2016) 'Czy w Muzeum Naprawdę Wszystko Wolno, Czyli o Procesie Przygotowynwania Przez Dzieci Wystawy w Museum Narodowum w Warszawie' [Can anything really go in a museum; How the children prepared for the exhibition at the National Museum in Warsaw], in Muzeum Narodowe w Warszawie W MUZEUM WSZYSTKO WOLNO [THE ANYTHING GOES MUSEUM] [exhibition catalogue], 243-48, Warsaw: Muzeum Narodowe w Warszawie.

Kirshenblatt-Gimblett, B. (1998) Destination Culture: Tourism, Museums, and Heritage, Berkeley: University of California Press. 
Knapek A. (2016) 'W Muzeum Wszystko Wolno, Czyli Pięć Zmysłów Partycypacji' [Anything Goes Museum, or the Five Senses of Participation], Muzealnictwo (57) 139-48. http://cejsh.icm.edu.pl/cejsh/element/bwmeta1.element.ceon.elementcd5775d8-1a29-35b6-ad4c-16a4f5c71f21/c/139-148.pdf.

Kreps, C. (2011) 'Changing the Rules of the Road: Post-Colonialism and the New Ethics of Museum Anthropology', in Janet Marstine (ed) Routledge Companion to Museum Ethics: Redefining Museum Ethics for the Twenty-First Century Museum, 70-84, London: Routledge.

Lancy, D.F. (2008) The Anthropology of Childhood: Cherubs, Chattel, Changelings, Cambridge: Cambridge University Press.

Lehrer, E., Milton, C. and Patterson, M.E. (2011) Curating Difficult Knowledge: Violent Pasts in Public Places, New York: Palgrave Macmillan.

Levine, R.A., Dixon, S., Levine, S., Richman, A., Leiderman, P.H., Keefer, C.H. and Brazelton, T.B. (1994) Childcare and Culture: Lessons from Africa, New York: Cambridge University Press.

Linenthal, E. (2001) Preserving Memory: The Struggle to Create America's Holocaust Museum, New York: Columbia University Press.

Lorente, J.P. (2015) 'Current Museological Strategies Related to Critical Museology', Complutum, 26 (2) 111-20. doi:10.5209/rev_CMPL.2015.v26.n2.50422.

Mairesse, F. and Desvallées, A. (2010) Key Concepts of Museology, Paris: International Council of Museums and Armand Colin.

Mallos, M. (2012) 'Collaboration is the Key: Artists, Museums, and Children', Journal of Museum Education, 37 (1) 69-80.

Mayfield, M.I. (2005) 'Children's Museums: Purposes, Practices and Play?', Early Child Development and Care 175 (2) 179-92.

Montgomery, H. (2009) An Introduction to Childhood: Anthropological Perspectives on Children's Lives, Chichester: Wiley-Blackwell.

Morawińska, A. (ed) (2017) The 'Anything Goes' Museum, Warsaw: National Museum in Warsaw.

Murawska-Muthesius, K. and Piotrowski, P. (2015) From Museum Critique to the Critical Museum, London: Routledge.

Muzeum Narodowe w Warszawie (2016) W MUZEUM WSZYSTKO WOLNO [THE ANYTHING GOES MUSEUM] [exhibition catalogue], Warsaw: Muzeum Narodowe w Warszawie.

Patterson, M.E. (2016) 'By and For Children: History and Healing in a Hospital Museum in KwaZulu Natal', in Shelley Ruth Butler and Erica Lehrer (eds) Curatorial Dreams: Critics Imagine Exhibitions, 82-104, Montreal: McGill-Queens University Press.

Patterson, M.E. and Friend, R. (2021) 'Beyond Window Rainbows: Collecting Children's Culture in the COVID Crisis', Collections, 17 (2) 167-78 (published online ahead of print 14 December 2020). doi:10.1177/1550190620980836_

Povis, T. and Elizabeth, K. (2016) Designing for Family Learning in Museums: How Framing, Joint Attention, Conversation, and Togetherness are at Play, University of Pittsburgh: Doctoral Dissertation http://proxy.library. carleton.ca/login?url=https://search-proquest-com.proxy.library.carleton.ca/ docview/1883363266?accountid=9894. 
Rakoczy, M. (2017) 'Czy w Muzeum Wszystko Wolno? Problemy z Nowoczesnym Pajdocentryzmem [Does anything really go in a museum? Questioning Modern Pedagogy in which Children are Central in Making Decisions in the Educational Process]', Pismo: Theories and Practices of Visual Culture, 19. http://pismowidok. org/index.php/one/article/view/496/1073.

Roberts, S. (2006) 'Minor Concerns: Representations of Children and Childhood in British Museums', Museum \& Society, 4 (3) 152-65.

Sandell, R., Dodd, J. and Garland-Thomson, R. (2013) Re-Presenting Disability: Activism and Agency in the Museum, Abingdon: Taylor \& Francis.

Shelton, A. (1990) 'In the Lair of the Monkey: Notes Towards a Postmodern Museography', in Susan Pearce (ed) Objects of Knowledge, 78-102, London: Athlone Press.

Simon, N. (2010) The Participatory Museum, Santa Cruz: Museum 2.0.

Sleeper-Smith, S. (2009) Contesting Knowledge: Museums and Indigenous Perspectives, Lincoln: University of Nebraska Press.

Sullivan, N. and Middleton, C. (2019) Queering the Museum (Museums in Focus), London: Routledge.

Szostakowska, M. (2017) 'How to Measure Passion?' in Agnieszka Morawińska (ed) The 'Anything Goes' Museum, 87-95, Warsaw: National Museum in Warsaw.

Truth and Reconciliation Commission of Canada (2015) Final Report of the Truth and Reconciliation Commission of Canada: Honouring the Truth, Reconciling for the Future, Toronto: James Lorimer and Company Ltd., Publishers.

Vergo, P. (1989) The New Museology, London: Reaktion Books.

Villeneuve, P. and Love, A.R. (eds) (2017) Visitor-centered Exhibitions and Edu-curation in Art Museums, Lanham, MD: Rowman \& Littlefield.

Walkerdine, V. (2009) 'Developmental Psychology and the Study of Childhood', in Mary Jane Kehily (ed) An Introduction to Childhood Studies, 112-23, Maidenhead: McGraw-Hill and Open University Press.

Watson, S. (2007) Museums and their Communities. Abingdon: Taylor and Francis Ltd.

Wood, E., Zemanek, A., Weiss, L. and Carron, C.G. (2016) 'Growing FLORES for the Museum', Collections: A Journal for Museum and Archives Professionals, 12 (1) 7-21. doi:10.1177/155019061601200102.

Young, J. (1994) The Texture of Memory: Holocaust Memorials and Meaning, Yale University Press.

\section{Author}

Monica Eileen Patterson

Carleton University

Ottawa

Canada

monica.patterson@carleton.ca

Monica Eileen Patterson is Assistant Director of the Institute for Comparative Studies in Literature, Art, and Culture (Curatorial Studies) at Carleton University in Ottawa, Canada. 
